ROCZNIKI HUMANISTYCZNE

Tom LXVIII, zeszyt $3-2020$

DOI: http://dx.doi.org/10.18290/rh20683-7

AGNIESZKA STRYCHARCZUK

KS. JAROSŁAW R. MARCZEWSKI

\title{
APOTEOZA GODŁA HERALDYCZNEGO \\ BISKUPA JÓZEFA MARCELEGO DZIĘCIELSKIEGO (1768-1839) \\ W ŁACIŃSKICH WIERSZACH HERBOWYCH W RUBRYCELACH LUBELSKICH
}

Józef Marceli Dzięcielski urodził się w 1768 r. w Torzewie na Kujawach. W 1787 r. wstąpił do seminarium duchownego we Włocławku, jednak już po roku wyjechał do Rzymu, gdzie kontynuował studia na Uniwersytecie Gregoriańskim. Tam też w 1792 r. uzyskał stopnie doktora filozofii i teologii oraz przyjął święcenia kapłańskie. W 1800 r. wszedł w skład gremium kanoników kapituły katedralnej we Włocławku, a w 1809 r. został jej prepozytem. Pełnił szereg ważnych funkcji kościelnych, będąc prowizorem seminarium włocławskiego, sędzią surogatem, a następnie oficjałem w konsystorzu, proboszczem w Izbicy, Piotrkowie i katedrze włocławskiej. Otrzymawszy nominację na sufragana nowo utworzonej diecezji kujawsko-kaliskiej, w $1820 \mathrm{r}$. przyjął sakrę biskupią. Wkrótce, po zawakowaniu rodzinnej diecezji, został przedstawiony jako kandydat na ordynariusza, jednak nie uzyskał niezbędnej aprobaty władz państwowych. W Lublinie natomiast, wybrany najpierw administratorem sede vacante, pod koniec 1825 r. otrzymał papieską prekonizację i w niedługim czasie objął diecezję lubelską. Chętnie posługiwał się listami pasterskimi. Przygotował diecezjalne obchody jubileuszu powszechnego w $1826 \mathrm{r}$. W latach 1830-1835 prowadził z pomocą współpracowników

Dr AgnieszKa StrycharczuK - Studium Praktycznej Nauki Języków Obcych Katolickiego Uniwersytetu Lubelskiego Jana Pawła II, Al. Racławickie 14, 20-950 Lublin, e-mail: Agnieszka. Strycharczuk@kul.pl; ORCID 0000-0002-0785-6069.

Ks. dr hab. JAROSŁAW R. MARCZEWSKI - Instytut Nauk Teologicznych, Wydział Teologii Katolickiego Uniwersytetu Lubelskiego Jana Pawła II, Al. Racławickie 14, 20-950 Lublin, adres do korespondencji: ul. Prymasa Stefana Wyszyńskiego 6, 20-105 Lublin, e-mail: jmarcz@kul.pl; ORCID 0000-0002-7021-6806. 
wizytację parafii w diecezji. W czasie powstania listopadowego czynnie angażował się w działalność patriotyczną zarówno na poziomie sejmowym, jak też $\mathrm{w}$ ramach swojej działalności pasterskiej w diecezji. W roku 1832 zakończył dzieło remontu katedry w Lublinie. Zmarł w 1839 r. w swojej rezydencji w Kumowie, gdzie został pochowany w miejscowym kościele ${ }^{1}$.

W dobie pełnienia przez biskupa Dzięcielskiego urzędu administratora, a następnie ordynariusza diecezji lubelskiej ukazało się 15 rubrycel przeznaczonych na kolejne lata w okresie od roku 1825 do roku 1839. Z wyjątkiem pierwszych dwóch wszystkie pozostałe zostały zaopatrzone w biskupi herb i stosowny, łaciński wiersz herbowy. Celem niniejszego artykułu - bazującego na zebranej w lubelskich instytucjach archiwalnych i bibliotecznych kolekcji rubrycel - pozostaje szczegółowa prezentacja wspomnianej twórczości oraz próba jej przekładu na język polski.

\section{WIERSZE HERBOWE}

Wacław Aleksander Maciejowski, XIX-wieczny badacz polskiego piśmiennictwa, znakomitą większość swego opracowania ${ }^{2}$ poświęcił twórcom niższego rzędu, a to dlatego, że uważał ich działalność za istotną dla ukazania pełnego obrazu ewolucji i finalnych dokonań literackich danego okresu. Szukając przyczyn obfitej aktywności mniej lub bardziej utalentowanych poetów działających w XVI wieku - zwanych przez niego „pisarkami” twierdził, że kierowała nimi jakaś „nieodgadniona żądza [...], by do ogólnej liczby wielkiego literatury ojczystej kapitału dorzucić coś z własnej chudoby,

\footnotetext{
${ }^{1}$ Michał GodlewsKI, „Dzięcielski Józef Marcelin”, w Polski słownik biograficzny, t. VI (Kraków: Polska Akademia Umiejętności, 1948), 179; Jan SKARBEK, „Dzięcielski Józef Marceli”, w Encyklopedia katolicka, t. IV (Lublin: Towarzystwo Naukowe KUL, 1983), 614; Zygmunt STARNAWSKI, „Józef Marcelin Dzięcielski 1768-1839, biskup lubelski 1826-1839”, Wiadomości Diecezjalne Lubelskie 59, nr 5-7(1985): 117-119; Kazimierz GROTNIK, Józef Marcellin Dzięcielski (biskup lubelski) 1825-1839 (Hazleton: K. Grotnik, 1988); Jarosław R. MARCZEWSKI, „Programowy list pasterski biskupa Józefa Marcelego Dzięcielskiego z 1827 roku”, Wiadomości Archidiecezji Lubelskiej 80, nr 2(2006): 499-521; Jarosław R. MARCZEWSKI, „Czas i miejsce urodzenia dwóch biskupów lubelskich: Józefa Marcelego Dzięcielskiego i Wincentego a Paulo Pieńkowskiego”, Archiwa Biblioteki i Muzea Kościelne 88(2007): 65-75; Marek DzIĘCIELSKI, „Józef Marcellin Dzięcielski (1768-1839), biskup lubelski (1825-1839)”, Studia Pelplińskie 42(2010): 75-101.

2 Wacław Aleksander MAciejowski, Piśmiennictwo polskie od czasów najdawniejszych aż do roku 1830, t. I-IV (Warszawa: Nakładem S. Orgelbranda, 1851-1852).
} 
żadnego przy tym, prócz powszechnego dobra, nie mając celu"3. Ów twórczy altruizm cechował nie tylko możnych, którzy komponując okolicznościowe wiersze posiłkowali się własnymi umiejętnościami lub „czepiąc się utalentowanych mężów", ale także zwykłych obywateli trudniących się rzemiosłem lub jakimkolwiek zarobkowaniem. Trudno rozstrzygnąc ilu z owych „pisarków" poczytywało sobie działalność literacką za dopełnienie miłości ojczyzny i społecznej służby, a ilu skłaniało się ku niej z pobudek koniunkturalnych, licząc na łaskawość mecenasów. Badania nad dziejami literatury polskiej pokazują, że niezależnie od motywów, jakimi się kierowali, efekty ich twórczej nieporadności stały się znakomitym tłem dla uwydatnienia kunsztu tych najwybitniejszych i znacznie poszerzyły obraz rodzimych dokonań ${ }^{4}$.

Dobrym przyczynkiem do tego typu rozważań może być poetycka działalność kontynuatorów wspomnianych „pisarków”, wywodzących się z kręgów duchownych i świeckich, spośród członków katedralnych kapituł lub grona sekretarzy i notariuszy, pracujących w biskupich kancelariach zadwornych u schyłku doby staropolskiej i na początku XIX wieku. Ich dzieła, choć pod względem artystycznych dokonań błąkają się na obrzeżach literatury, stają się owym koniecznym tłem i elementem literackiego dorobku epoki.

Choć wiersze na herby pojawiają się w literackim obiegu już od $1515 \mathrm{r}$. i są związane z książką drukowaną ${ }^{5}$, rzadko zdarza się, by w odnoszących się do nich współczesnych opracowaniach sięgano do publikacji ściśle użytkowych, którymi pozostają rubrycele, zwane też dyrektoriami. Druki te, przeznaczone na konkretny rok, będące kalendarzem liturgicznym zawierającym informacje dotyczące porządku obchodów i ceremonii w danym Kościele partykularnym, opatrzone były zwyczajowo herbem biskupa diecezji, jako że wychodziły pod auspicjami pasterza. Znakomita większość hierarchów jeszcze w XIX wieku wywodziła się z rodów szlacheckich, pieczętujących się stosownymi herbami. To z kolei dawało asumpt uzdolnionym poetycko współpracownikom biskupim, czy też wynajętym „pisarkom”, do opatrzenia tychże herbów odpowiednim adresem. W ten sposób stanowiący obraz herb biskupi wraz z epigramem będącym subskrypcją tworzyły razem tak popularny w literaturze polskiej stemmat. W przypadku analizowanych w niniejszym

\footnotetext{
${ }^{3}$ Maciejowski, Piśmiennictwo, t. II, 182-183.

${ }^{4}$ Franciszek PILARCZYK, Stemmata $w$ drukach polskich XVI wieku (Zielona Góra: Wydawnictwo Wyższej Szkoły Pedagogicznej, 1982), 5: „Takie samo jak Maciejowski stanowisko w omawianej sprawie zajmował Aleksander Brückner, który niejednokrotnie podkreślał konieczność badania marginesów twórczości literackiej okresu staropolskiego. Uważał bowiem, że dla pełnego obrazu kultury wybranego okresu konieczna jest także znajomość «twórczości» wyrobników literatury”.

${ }^{5}$ PilarczyK, Stemmata, 6.
} 
artykule zestawień specyfikacja ta nie podlega wątpliwości, gdyż elementem wskazującym na gatunek jest występujący nadpis: Stemma Illustrissimi, Excellentissimi ac Reverendissimi Domini $[\ldots]^{6}$.

Wiersze na herby umieszczone we wspomnianej konstrukcji nie zawierały elementów popisowych, gdyż z zasady miały charakter anonimowy ${ }^{7}$. Ich celem była pochwała biskupa diecezji, nie zaś uwydatnienie kunsztu autora. Twórcy epigramatów starali się przede wszystkim o nakierowanie uwagi odbiorców na te wszystkie cnoty pasterza, które mogły stanowić przykład do naśladowania dla całego duchowieństwa. Tym samym ich utwory spełniały ważną funkcję dydaktyczną. W wielu omawianych poniżej epigramatach brak zatem wymaganych aluzji do herbu.

W analizowanym zbiorze epigramatów poświęconych biskupowi Dzięcielskiemu część utworów nie stanowi twórczego novum, lecz jest przedrukiem

\footnotetext{
${ }^{6}$ Wyczerpujące informacje na temat rozumienia terminu stemmat w wydaniach o charakterze słownikowym i praktyce literackiej podaje Bartłomiej CzARSKI, Stemmaty w staropolskich ksiażkach, czyli rzecz o poezji heraldycznej (Warszawa: Muzeum Pałac w Wilanowie, 2012), 62-75. Należy jednak zwrócić uwagę na niejednoznaczność w zakresie specyfikacji gatunku; Janusz PelC, Obraz - stowo - znak. Studium o emblematach w literaturze staropolskiej (Wrocław: Zakład Narodowy im. Ossolińskich, 1973), 14: „poprzedniczką renesansowej emblematyki była, przynajmniej w pewnym zakresie, średniowieczna heraldyka, średniowieczne stemmata, czyli wiersze na godła herbowe”; tamże, 33: „Granica między imagines i stemmata była w XVI w. niekiedy dość płynna, podobnie jak między emblemata i imagines. Czynnikiem ułatwiającym upodobnienia i zacieranie granic było zapewne to, iż w funkcji subskrypcji w tych trzech pokrewnych strukturach (a więc w jej części literackiej, poetyckiej, pisanej), występowały zazwyczaj epigramaty posiadające własną poetykę, własną wielowiekową tradycję. Ponadto przypomnieć warto, że właściwie wszystkie trzy wymienione konstrukcje gatunkowe przechodziły w XVI wieku ze szczególną gwałtownością proces kompozycji i dekompozycji, którym gatunki i rodzaje literatury oraz innych sztuk podlegają zawsze"; Paulina Buchwald-PelcowA, Emblematy w drukach polskich i Polski dotyczacych XVIXVIII w. (Wrocław: Zakład Narodowy im. Ossolińskich, 1981), 11: „W drukach tłoczonych w Polsce szczególnie trudno jest czasem postawić granicę między emblematami i różnego rodzaju konstrukcjami słowno-plastycznymi, w których główną rolę odgrywał herb, od wierszy na herby aż do publikacji typu vita czy icones, przy których w Polsce zwykle podawano zamiast podobizn osób ich herby”. Szerzej o problemie Paulina Buchwald-Pelcowa, „Na pograniczu emblematów i stemmatów", w Słowo i obraz. Materiały sympozjum Komitetu Nauk o Sztuce Polskiej Akademii Nauk, Nieborów, 29 września - 1 października 1977, red. Agnieszka Morawińska (Warszawa: Państwowe Wydawnictwo Naukowe, 1982), 73-95.

${ }^{7}$ PILARCZYK, Stemmata, 81: „Obok autorów ogólnie znanych i cenionych za swoją rozległą twórczość literacką wiersze na herby tworzyli bardzo liczni autorzy z literaturą mający niewiele wspólnego [...]. Znaczna część wierszy to utwory anonimowe, inne podpisane są kryptonimem trudnym dziś do rozszyfrowania". Warto wszakże zwrócić uwagę na występujące niekiedy odstępstwa od tej zasady. Przykładowo w rubrycelach chełmskich na lata 1711 oraz 1719 znalazły się nazwiska autorów. Byli to odpowiednio Tomasz Gruszecki i Albert Zieliński, obaj piastujący w swoim czasie funkcję wicekustosza zamojskiej kapituły kolegiackiej; Karol EsTREICHER, $B i$ bliografia polska, cz. 3, t. XV (Kraków: Akademia Umiejętności, 1897), 214.
} 
z wcześniejszych publikacji, które opatrzone były herbem Leszczyc należącym do biskupa Wojciecha Skarszewskiego, będącego w latach 1790-1824 pasterzem diecezji chełmskiej, a potem lubelskiej ${ }^{8}$. Bez wątpienia bezpośrednie następstwo biskupa Dzięcielskiego na lubelskiej stolicy biskupiej miało wpływ na powtórzenie epigramatów, dokonane zapewne ręką tego samego autora. Uwiarygodnia to także wyżej postawioną tezę, że nadrzędnym motywem utworów pozostawała pochwała biskupich cnót, które powinny stanowić pewien oczywisty zasób w przypadku każdego pasterza diecezji, niezależnie od tego, jakim herbem się pieczętował.

Wiersze herbowe zawarte $\mathrm{w}$ rubrycelach pozostają nie tylko specyficznym elementem literatury szlacheckiej związanej z tym stanem społecznym, ale też świadectwem jego promieniowania na inne stany. Diecezjalni duszpasterze, a także krąg ich współpracowników, to niemałe grono czytelników, które - choć nie zawsze miało odpowiednie przygotowanie do odbioru tego typu twórczości - jednak zawsze z uwagą śledziło urzędowe dyrektoria. Trudno zatem pominąć starania anonimowych „wyrobników literatury", którzy idąc za wskazaniami mistrzów i nie zawsze dotrzymując im kroku, przyczynili się do rozwoju poezji herbowej w początkowych latach XIX wieku.

\section{ANALIZA WIERSZY}

Nominacja i objęcie urzędu przez nowego pasterza diecezji lubelskiej stały się niewątpliwie inspiracją dla miejscowych autorów wierszy herbowych. Była to twórczość może niezbyt wysokich lotów, ale ukazująca silne tendencje panegiryczne zgodne z duchem epoki. Pojawienie się nowego biskupa było okazją do wyrażenia słów powitania, złożenia życzeń, bliższego przedstawienia pasterza gronu duchownych i świeckich poprzez skierowanie ich uwagi na jego cnoty ${ }^{9}$. Wszystkie te elementy znalazły najpierw swoje miejsce $\mathrm{W}$ utworze anonimowego autora określającego siebie mianem

\footnotetext{
${ }^{8}$ Wiersze herbowe poświęcone temu biskupowi zostały omówione w artykule: Agnieszka STRYCHARCZUK i Jarosław R. MARCZEWSKI, „Apoteoza godła heraldycznego biskupa Wojciecha Skarszewskiego w łacińskich wierszach herbowych w rubrycelach chełmsko-lubelskich i lubelskich", Roczniki Humanistyczne 63, z. 3(2015): 149-176.

${ }^{9}$ PILARCZYK, Stemmata, 81: „Wiersze umieszczone pod herbami dają zwykle religijną interpretację godła herbowego biskupa, najczęściej wspominają o jego walce z herezją i odszczepieństwem, chwalą łagodność [...] i wspomaganie ubogich".
} 
„Właściwego Dyecezanina z Dekanatu Chodelskiego"10. Co ciekawe, punktem odniesienia stał się dla niego - przypisywany biskupowi - herb Jastrzębiec. Taką samą nazwę herbu znajdujemy także w rubrycelach wydawanych na lata 1825-1829, najpierw mocą autorytetu biskupa Dzięcielskiego jako administratora sede vacante, a potem już jako nowego ordynariusza ${ }^{11}$. Tymczasem w kolejnych rubrycelach, przeznaczonych na lata 1830-1839, eksponowana była zawsze nazwa herbu Korwin ${ }^{12}$. O większym jeszcze zamieszaniu

${ }^{10}$ Wiersz powitania Jaśnie Wielmożnego Józefa Marcellina Dzięcielskiego, Biskupa Lubelskiego, Senatora Królestwa Polskiego, roku 1826 w dniu 26 kwietnia jako w dzień imienin przez Właściwego Dyecezanina z Dekanatu Chodelskiego z przynależna skromnościa ofiarowany (bmw, [1826]).

${ }^{11}$ Ordo Divini Officii ad usum Dioecesis Lublinensis pro Anno Domini 1825. Authoritate et mandato Illustrissimi Excellentissimi ac Reverendissimi Domini Josephi Marcellini Jastrzębiec Dzięcielski Dei et Apostolicae Sedis gratia Episcopi Aratensis, Suffraganei et Praepositi Cathedralis Calissensis, Sede vacante Administratoris Generalis Dioecesis Lublinensis etc. etc. propositus (Varsaviae: Ad Sanctam Crucem, [1824]); Ordo Officii Divini ad usum Dioecesis Lublinensis pro Anno Domini 1826. Authoritate et mandato Illustrissimi Excellentissimi ac Reverendissimi Domini, Domini Josephi Marcellini Jastrzębiec Dzięcielski Episcopi Lublinensis propositus (Varsaviae: Ad Sanctam Crucem, [1825]); Ordo Officii Divini ad usum Dioecesis Lublinensis pro Anno Domini 1827. Propositus authoritate et mandato Illustrissimi Excellentissimi ac Reverendissimi Domini, Domini Josephi Marcellini Jastrzębiec Dzięcielski Episcopi Lublinensis (Varsaviae: Ad Sanctam Crucem, [1826]); Ordo Officii Divini ad usum Dioecesis Lublinensis pro Anno Domini Bissextili MDCCCXXVIII propositus authoritate et mandato Illustrissimi Excellentissimi ac Reverendissimi Domini, Domini Josephi Marcellini Jastrzębiec Dzięcielski Episcopi Lublinensis (Varsaviae: Ad Sanctam Crucem, [1827]); Ordo Officii Divini ad usum Dioecesis Lublinensis pro Anno Domini MDCCCXXIX propositus authoritate et mandato Illustrissimi Excellentissimi ac Reverendissimi Domini, Domini Josephi Marcellini Jastrzębiec Dzięcielski Episcopi Lublinensis (Varsaviae: Ad Sanctam Crucem, [1828]).

12 Ordo Officii Divini ad usum Dioecesis Lublinensis pro Anno Domini MDCCCXXX propositus authoritate et mandato Illustrissimi Excellentissimi ac Reverendissimi Domini, Domini Josephi Marcellini Korvin Dzięcielski Episcopi Lublinensis, Senatoris Regni Poloniae, Magnae Crucis S. Stanislai Equitis Commendatoris (Varsaviae: Ad Sanctam Crucem, [1829]); Ordo Officii Divini ad usum Dioecesis Lublinensis pro Anno Domini MDCCCXXXI propositus authoritate et mandato Illustrissimi Excellentissimi ac Reverendissimi Domini, Domini Josephi Marcellini Korvin Dzięcielski Episcopi Lublinensis, Senatoris Regni Poloniae, Magnae Crucis S. Stanislai Equitis Commendatoris (Varsaviae: Ad Sanctam Crucem, [1830]); Ordo Officii Divini ad usum Dioecesis Lublinensis pro Anno Domini MDCCCXXXII Bissextili propositus authoritate et mandato Illustrissimi Excellentissimi ac Reverendissimi Domini, Domini Josephi Marcellini Korwin Dzięcielski Episcopi Lublinensis, Senatoris Regni Poloniae, Magnae Crucis ac S. Stanislai Equitis Commendatoris (Varsaviae: Ad Sanctam Crucem, [1831]); Ordo Officii Divini ad usum Dioecesis Lublinensis pro Anno Domini MDCCCXXXIII post bissextilem embolismalem primo propositus authoritate et mandato Illustrissimi Excellentissimi ac Reverendissimi Domini, Domini Josephi Marcellini Korwin Dzięcielski Episcopi Lublinensis, Senatoris Regni Poloniae, ac Magnae Crucis S. Stanislai Equitis Commendatoris (Varsaviae: Ad Sanctam Crucem, [1832]); Ordo Officii Divini ad usum Dioecesis Lublinensis pro Anno Domini Embolismali MDCCCXXXIV post bissextilem secundo propositus authoritate et mandato Illustrissimi Excellentissimi ac Reverendissimi Domini, Domini Josephi 
dotyczącym rodowego herbu lubelskiego pasterza - w tym o dodatkowej nazwie herbu Ślepowron - można się przekonać, studiując zarówno wcześniejsze herbarze, jak i współczesną literaturę przedmiotu ${ }^{13}$. Pojawia się również i taka wiadomość, że Dzięcielscy z linii kujawskiej, z której wywodził się biskup, pieczętowali się herbem Dzięcioł, zaś inne asocjacje są wytworem heraldyków i nie potwierdzają porzucenia herbu przez rodzinę biskupa ${ }^{14}$. Dostępny stan badań nie pozwala na wyjaśnienie, dlaczego jednak w drukach większości rubrycel oraz $\mathrm{w}$ tekście epitafium umieszczonego w lubelskiej archikatedrze ${ }^{15}$ przy personaliach biskupa pojawia się nazwa herbu Korwin. Trudno przypuszczać, żeby sam biskup Dzięcielski nie miał wpływu na formę i treść dyrektoriów, zatem posługiwanie się taką nazwą herbu było przezeń w pełni świadome i akceptowane.

Warto doprecyzować, że niezależnie od nazwy wizerunek herbowy w rubrycelach był zawsze dokładnie taki sam: w polu kruk - po łacinie corvus, stąd spolszczona nazwa herbu Korwin - na gałęzi z pierścieniem w dziobie, w klejnocie taki sam kruk; druk czarno-biały nie pozwalał na odwzorowanie barw herbowych. Dla porządku trzeba zaznaczyć, że rubrycele lubelskie na

Marcellini Korwin Dzięcielski Episcopi Lublinensis, Magnae Crucis ac S. Stanislai Equitis Commendatoris (Varsaviae: Ad Sanctam Crucem, [1833]); Ordo Officii Divini ad usum Dioecesis Lublinensis pro Anno Domini MDCCCXXXV post bissextilem tertio propositus authoritate et mandato Illustrissimi Excellentissimi ac Reverendissimi Domini, Domini Josephi Marcellini Korwin Dzięcielski Episcopi Lublinensis, Magnae Crucis ac S. Stanislai Equitis Commendatoris (Varsaviae: Ad Sanctam Crucem, [1834]); Ordo Officii Divini ad usum Dioecesis Lublinensis pro Anno Domini Bissextili MDCCCXXXVI propositus authoritate et mandato Illustrissimi Excellentissimi ac Reverendissimi Domini, Domini Josephi Marcellini Korwin Dzięcielski Episcopi Lublinensis, Magnae Crucis ac S. Stanislai Equitis Commendatoris (Varsaviae: Ad Sanctam Crucem, [1835]); Ordo Officii Divini ad usum Dioecesis Lublinensis pro Anno Domini MDCCCXXXVII propositus authoritate et mandato Illustrissimi Excellentissimi ac Reverendissimi Domini, Domini Josephi Marcellini Korwin Dzięcielski Episcopi Lublinensis, Magnae Crucis ac S. Stanislai Equitis Commendatoris (Varsaviae: Ad Sanctam Crucem, [1836]); Ordo Officii Divini ad usum Dioecesis Lublinensis pro Anno Domini MDCCCXXXVIII propositus authoritate et mandato Illustrissimi Excellentissimi ac Reverendissimi Domini, Domini Josephi Marcellini Korwin Dzięcielski Episcopi Lublinensis, Magnae Crucis ac S. Stanislai Equitis Commendatoris (Varsaviae: Ad Sanctam Crucem, [1837]); Ordo Officii Divini ad usum Dioecesis Lublinensis pro Anno Domini MDCCCXXXIX propositus authoritate et mandato Illustrissimi Excellentissimi ac Reverendissimi Domini, Domini Josephi Marcellini Korwin Dzięcielski Episcopi Lublinensis, Magnae Crucis ac S. Stanislai Equitis Commendatoris (Varsaviae: Ad Sanctam Crucem, [1838]).

${ }^{13}$ Adam Boniecki, Herbarz polski, t. V (Warszawa: Gebethner i Wolff, 1902), 210; Seweryn URUSKI, Rodzina. Herbarz szlachty polskiej, t. III (Warszawa: Gebethner i Wolff, 1906), 364; GrotniK, Józef Marcellin Dzięcielski, 8; Szlachta wylegitymowana w Królestwie Polskim w latach 1836-1861, oprac. Elżbieta Sęczys (Warszawa: Wydawnictwo DiG, 2000), 152.

${ }^{14}$ DZIĘCIELSKI, Józef Marcellin Dzięcielski, 80.

${ }^{15}$ Odnośny fragment brzmi: „Josepho Marcellino de Korwin Dzięcielski”. 
lata 1825-1826 nie zawierały wyobrażenia herbowego ani epigramatu, nazwa herbu występowała jedynie w tytule publikacji przy nazwisku biskupa. W kolejnych rubrycelach biskupa Dzięcielskiego, zgodnie z panującym wówczas zwyczajem, herb i epigramat były konsekwentnie umieszczane na drugiej stronie karty tytułowej, inaczej niż było to w przeszłości, gdy w rozmaitych wydawnictwach wykorzystywano w tym celu pierwszą stronę ${ }^{16}$.

Chociaż naturalnym odniesieniem do wierszy herbowych powinien być właśnie herb biskupa, niemniej nie wszystkie epigramaty zawierały nawiązujące do niego aluzje. Sławiły natomiast zawsze biskupie cnoty. Nawiązania do herbu znajdziemy właściwie tylko w czterech epigramatach: IV, X, XI, XII ${ }^{17}$. W epigramacie IV autor wspomina o umieszczeniu herbu na karcie tytułowej rubryceli, dokonując przy tym personifikacji herbowego klejnotu. Kruk uosabia biskupa, który wskazuje drogę wiernym, oni zaś odwzajemniają się życzeniami, by nie brakowało mu duchowego pokarmu i długiego życia. Ciekawą inspiracją dla takiej treści mógł być biblijny motyw kruka, który był narzędziem Bożej opatrzności i dostarczał pokarm wybranym przez Boga ${ }^{18}$. Do takiego właśnie epizodu ze Starego Testamentu (1 Krl 17,4-6) nawiązał w jednym ze swoich utworów barokowy moralista Wacław Potocki:

Rozkazał Bóg krukowi żywić Eliasza

Aż on chleb, aż on mięso do Lassa mu znasza.

Póki król Achab na Proroki dycha,

Miły Boże! Ktoby rzekł, że ptaszyna licha

Wie komu być posłusznym? Niech ten przykład kruczy,

Więcej Boga, niż ludzi, wszytkich słuchać uczy ${ }^{19}$.

Pouczenie zawarte w ostatnim dwuwierszu, uniwersalne i zarazem bliskie nie tylko kręgom duchownym, może być pomocne w odczytaniu metafory

\footnotetext{
16 PILARCZYK, Stemmata, 81.

${ }^{17}$ Utwory przedstawione w niniejszym artykule zostały umieszczone w porządku chronologicznym. Początkowe daty informują o roku, na który wychodziły kolejne edycje rubrycel. Na użytek niniejszego opracowania i tłumaczenia zastosowano numerację odpowiadającą ogólnej liczbie epigramatów (I-XIII).

${ }^{18}$ Dorothea ForSTnER, Świat symboliki chrześcijańskiej, thum. i oprac. Wanda Zakrzewska, Paweł Pachciarek i Ryszard Turzyński (Warszawa: Instytut Wydawniczy PAX, 1990), 237-238. Choć autorka przytacza także liczne przykłady negatywnych cech kruka w literaturze chrześcijańskiej, to warto zwrócić uwagę na fakt, że sama legenda opowiadająca o powstaniu herbu Korwin podaje pozytywną rolę tego stworzenia w bitwie, którą stoczył rzymski polityk Marcus Valerius Messala Corvinus; Kasper Niesiecki, Herbarz polski, wyd. Jan Nepomucen Bobrowicz, t. V (Lipsk: Breitkopf i Haertel, 1840), 245-246.

${ }^{19}$ Wacław Pотоскі, Poczet herbów szlachty Korony Polskiej i Wielkiego Księstwa Litewskiego, wstęp i oprac. Dariusz Dybek (Warszawa: Raphael, 2008), 145-146.
} 
obecnej w epigramacie. Duchowa strawa, której wierni oczekują od swego pasterza, jest częstym elementem topiki wierszy herbowych dedykowanych kapłanom różnych stopni i godności.

W epigramacie $\mathrm{X}$ autor bezpośrednio nawiązuje do sanguis priscus - prastarej krwi rodu, która sama z siebie jest powodem do chluby, jednak wyższą wartość przypisuje cnotom i prawości. Szlacheckie pochodzenie biskupa uzyskuje dopełnienie dzięki zaletom dobrego pasterza, których on jest uosobieniem. Dosyć konwencjonalny wydaje się passus wskazujący na fakt, że biskup Dzięcielski mniejszą wartość przypisuje szlacheckiemu rodowi, który ma znaczenie jedynie w ziemskim porządku życia, a bardziej ceni wartości nieprzemijające: virtus et proba vita. Podobny fragment pojawia się $\mathrm{w}$ epigramacie XI, gdzie virtus superat stemmata clara. Oczywiście nie należy tutaj winić autora za przywiązanie do pewnych schematów naturalnych dla sfery duchownej, mniej oczywistych z punktu widzenia literackiego kunsztu. Owe powtórzenia dowodzą nie tyle realnej deprecjacji rodowego herbu, ile pewnego przewartościowania. Taki zabieg stanowił zapewne jasny sygnał dla lubelskiego kleru odnośnie do stosowania właściwej hierarchii dóbr.

Zgoła inna konwencja pojawia się w epigramacie XII, który nawiązuje do mitologicznej historii ukazanej w Metamorfozach Owidiusza ${ }^{20}$. Herbowy kruk zmienia się w Filomelę - słowika, lecz autor utworu mówi nie tylko o zmianie głosu, lecz także obyczajów. Ten niewątpliwie erudycyjny element nakierowuje odbiorcę na alegoryczną interpretację wspomnianej metamorfozy. Być może autor epigramatu chciał wprowadzić do swojego utworu element popisowy i zgrabnie wykorzystać Owidiuszowy wątek. Nie chodziło rzecz jasna o bezpośrednią aluzję do tegoż motywu, a jedynie zastosowanie efektownej figury stylistycznej w postaci antytezy kruk - słowik. Głos biskupa porównany jest do śpiewu słowika i natchnienia, jakie dają Muzy. Metafora o tyle uprawniona, o ile nawiązująca do pewnej tradycji literackiej obecnej chociażby w wierszu na ten sam herb Korwin, którym pieczętował się Jan Kochanowski:

Mogłać ziemia węgierska mieć z klejnotu tego

Króla, w sprawach rycerskich dosyć fortunnego,

Nie podlejszą ozdobę to królestwo niesie

${ }^{20}$ Owidiusz, Przemiany, tłum. Bruno Kiciński, oprac. Aleksander Krawczuk (Warszawa: Unia Wydawnicza „Verum”, 1995), VI, 417-680. Filomela siostra Prokne, żony króla Daulis w Fokidzie Tereusa. Tereus zgwałcił Filomelę i uciął jej język, aby nie powiedziała Prokne o zdradzie. Filomela utkała szatę, i w jej deseniu umieściła słowa, dzięki którym Prokne dowiedziała się o losie swej siostry. Mszcząc się, siostry zabiły Itysa - syna Prokne i Tereusa - i jego ciało podały w potrawie Tereusowi. By uniknąć zemsty króla, dzięki interwencji bogów siostry zostały zamienione w ptaki. Filomela w słowika, a Prokne w jaskółkę. 
Z Jana Kochanowskiego, który w Czarnym Lesie,

Wsi ojczystej, mieszkając, takim wierszem śpiewa,

Jakiego i Helikon podobno nie miewa.

A snadź by mieli mówić po polsku bogowie,

Iścieby z Kochanowskim przestali na mowie ${ }^{21}$.

Mistrz z Czarnolasu dzięki „śpiewaniu wierszem” mógłby niewątpliwie stanowić ozdobę Helikonu. Wielkość talentu, wdzięk mowy skłoniłyby nawet bóstwa niosące poetyckie natchnienie do posługiwania się językiem renesansowego autora. Podobnie głos pasterza diecezji lubelskiej rozchodzi się po świecie mu bliskim i dociera do samego Boga, wdzięczny i miły powinien być także dla powierzonych jego pieczy diecezjan.

Wykorzystanie inspiracji mitologicznych i biblijnych, choć rzadko pojawiające się w analizowanych wierszach, nie stanowi osobliwego wyjątku ${ }^{22}$. $\mathrm{W}$ epigramacie $\mathrm{V}$ pojawia się nawiązanie do postaci biblijnego patriarchy. Przyczynkiem do tego staje się zbieżność imion. Postać Józefa Egipskiego, którego misja ocaliła rodzinny dom od śmierci głodowej, stanowi paralelę dla biskupa Józefa, który powinien dać swemu ludowi duchowy pokarm wybawiający od śmierci wiecznej.

W pozostałych utworach można napotkać niezbyt wyszukane metafory pojawiające się także we wspomnianym już Wierszu powitania..., gdzie biskup Dzięcielski występuje jako Feb (łac. Sol) rozświetlający drogi swoich wiernych. Owa iluminacyjność (wyrażona w nagromadzeniu czasowników bliskoznacznych: fulgere, micare, radiare, nitere, clarere) jest elementem jego posługi, ale zwraca także uwagę na pewną wyższość, wyróżnik pełnionej funkcji względem duchowieństwa i powierzonego ludu. Tę prawdę podkreśla także wyraźna topika pasterska, gdzie słowa Pastor, Custos, Praesul, Antistes odnoszą się do opiekuńczej roli biskupa i związanej z nią czujności względem swojej trzody (Clerus, Plebs, Grex, Populus, Ovile). Przy tym wszystkie zalety charakteru eksponowane z emfazą, a także szlacheckie pochodzenie są niejako zaprzęgnięte do budowania wizerunku biskupa jako osoby budzącej zaufanie i dającej gwarancję utrzymania właściwego kierunku w trudnych czasach dla ojczyzny i diecezji.

Ważnym elementem kompozycyjnym analizowanych wierszy herbowych są życzenia dla biskupa Dzięcielskiego, nie tylko wiążące się z konwencją

${ }^{21}$ Bartosz PAProcki, Gniazdo cnoty (Kraków: Drukarnia Andrzeja Piotrowczyka, 1578), 1058; IDEM, Herby rycerstwa polskiego, wyd. Kazimierz Józef Turowski (Kraków: Wydawnictwo Biblioteki Polskiej, 1858), 708.

22 Tadeusz BIEŃKOwski, Antyk w literaturze i kulturze staropolskiej (1450-1750). Glówne problemy i kierunki recepcji (Wrocław: Zakład Narodowy im. Ossolińskich, 1976), 15. 
saecula mille, ale też odnoszące się do określonych oczekiwań: przynoszenia radości swym wiernym, pokonywania złych losów, podążania na przedzie drogi wiodącej ku zbawieniu i nagrody należnej od Boga za trud duszpasterskich wysiłków.

Trzeba przy tym pamiętać, że zastosowanie wyraźnej konwencji laudacyjnej, w której cnoty biskupa i wizja jego pasterskiej posługi były eksponowane z taką siłą, zaś asocjacje herbowe schodziły na dalszy plan, mogły być spowodowane sytuacją polityczną w kraju i administracyjną w samej diecezji. Wybuch powstania listopadowego i jego konsekwencje dotkliwie odbijały się na morale tak duchowieństwa, jak i świeckich. Po powstańczej klęsce na samego biskupa i wielu kapłanów spadły represje. Biskup Dzięcielski zaprzestał angażowania się $\mathrm{w}$ politykę $\mathrm{i}$ skupił na pracy duszpasterskiej ${ }^{23}$. Może dlatego rola biskupa jako duchowego przewodnika i nauczyciela niczym treściowy lejtmotyw i pium desiderium zarazem przewija się przez większość analizowanych epigramatów.

\section{ROZWIAZZANIA TRANSLATORSKIE}

Jak już wspomniano, „Właściwy Dyecezanin z Dekanatu Chodelskiego”, którego personalia nie zostały wyjawione potomnym, przygotował na cześć nowego pasterza diecezji lubelskiej okolicznościowy utwór, w którym z nieukrywaną radością i należną atencją pisał:

Wznoszę ręce za dary łaskawości Nieba.

Albowiem Ciebie mamy wspaniałego Feba.

Józefie Marcellinie, Biskupie Lubelski,

Herbu Jastrzębiec, Jaśnie Wielmożny Dzięcielski ${ }^{24}$.

Wspomniany utwór to pisany trzynastozgłoskowcem hymn pochwalny liczący ogółem 80 wersów, parzyście rymowany. Poprzedza go czterowersowy epigramat w języku łacińskim pisany dystychem elegijnym:

Sol fovet et lucet, sol praestat germina terrae,

Hae dotes Animi splendida signa Tui.

Corde foves Clerum, populum vehementis Amoris,

Crescit non modicum germen abinde Tibi.

\footnotetext{
${ }^{23}$ DzIĘCIELSKI, Józef Marcellin Dzięcielski, 91.

${ }^{24}$ Wiersz powitania, 17-20.
} 
Lektura Wiersza powitania... pozwala zauważyć, że w jego treści pojawiło się tłumaczenie przytoczonego epigramatu:

Feb ogrzewa, przyświeca, daje ziemi plony,

Umysł Twój jest przymioty temi ozdobiony.

Wzór cnót jest wzorem Twojej najwspanialszej duszy,

Lud, Kapłanów, Twa miłość serca dzielnie kruszy ${ }^{25}$.

Powyższe zestawienie może świadczyć o tym, że albo obydwa utwory poetyckie mają tego samego autora, albo autor hymnu pochwalnego wplótł zgrabnie w swój utwór treść epigramatu, dokonując jego tłumaczenia. To z kolei uprawnia do dywagacji na temat sposobu przekładu łacińskich epigramatów będących przedmiotem naszego zainteresowania. W przeciwieństwie do metody zastosowanej przez XIX-wiecznego „Dyecezanina”, przedstawione poniżej tłumaczenia nawiązują do formalnej strony oryginału. Przywołany łaciński epigram otwierający hymn pochwalny został przełożony przez autora w metrum trzynastozgłoskowym z cezurą po siódmej sylabie. Tłumaczenie wierszy herbowych zamieszczonych $\mathrm{w}$ niniejszym artykule prezentuje natomiast następujący układ: dwunastozgłoskowiec z cezurą po szóstej sylabie w wersach nieparzystych i dziewięciozgłoskowiec lub ośmiozgłoskowiec $\mathrm{z}$ cezurą po czwartej lub trzeciej sylabie w wersach parzystych. Jest to wybór na tyle słuszny, że z jednej strony nawiązuje do formalnej strony dystychu, ukazując jego asymetrię, z drugiej zaś przyczynia się do uzyskania efektu lekkości i tym samym wdzięczniejszego odbioru. Oczywiście konsekwencją takiej formy tłumaczenia jest częściowa rezygnacja z precyzji i dokładności w warstwie treściowej, które nie są w stanie zaistnieć ze względu na ograniczenia wymuszone określonym metrum ${ }^{26}$.

Stanisław Barańczak wybitny thumacz i literaturoznawca przypomina w jednym ze swoich opracowań „banalną prawdę: tłumaczenie poezji jest zawsze

\footnotetext{
${ }^{25}$ Wiersz powitania, 23-26.

${ }^{26}$ Kwestie te dobrze ilustruje wypowiedź odnosząca się do zupełnie innego przekładu: „Ale choć wiersz wydaje się tylko oznaką poetyckości tekstu i może jeszcze nosicielem jakiejś swoistej melodii, pełniącej niekiedy funkcję onomatopeiczną, to jednak już sam wybór - w wypadku wersyfikacji regularnej - określonego metrum pociąga za sobą cały szereg konsekwencji dla języka i stylu tekstu. Wchodzi tu w grę większa czy mniejsza (od średniej językowej) częstość występowania głosek i sylab określonego typu (w rymie), wyrazów o określonej rozpiętości sylabicznej i zestrojów o określonej długości i budowie akcentowej, określonych struktur składniowych, stosowanie pewnych figur rytmiczno-składniowych czy pojawianie się pewnych przebiegów intonacyjnych”; Lucylla PszczoŁowska, „Potęga metrum: o Puszkinowskim przekładzie Czat”, $\mathrm{Pa}$ miętnik Literacki 92, z. 3(2001): 171.
} 
aktem jej interpretacji”27. Wyjaśniając różnicę między terminami „tłumaczenie” i „przekład” konstatuje, że ten pierwszy „czynność przeniesienia tekstu w inny język traktuje jako czynność jego wyjaśniania, wyjaśniania opartego na rozumieniu i rozstrzyganiu. [...] Gotowe thumaczenie jest jak gdyby namacalnym, wymiernym dowodem, że się idealnie zrozumiało oryginał" 28 . Trudno nie zgodzić się z tym twierdzeniem, przy założeniu, że dysponuje się równym lub większym talentem co twórca oryginału, w przeciwnym razie pozostaje oprzeć się na Owidiuszowym Ut desint vires, tamen est laudanda voluntas.

W licznych publikacjach dotyczących translacji łacińskiej poezji ${ }^{29}$ często podnoszonym tematem jest znalezienie wzorca, który mógłby spełniać wszystkie wymagania. Jedno $\mathrm{z}$ najnowszych opracowań poświęconych stemmatom ujawnia bezpieczną receptę w postaci przekładu dystychu prozą ${ }^{30}$. Próby podejmowane przez tłumaczy obecnej doby podsuwają różne rozwiązania: od przedstawionego powyżej, poprzez metrum trzynastozgłoskowe, do form niemalże odwzorowujących antyczny dystych ${ }^{31}$. Należy przy tym zaznaczyć, że ostatecznie każdy tłumacz bierze na siebie konsekwencje związane $\mathrm{z}$ wybraną formą translacji, a jej ocenę pozostawia Lectori benigno oraz fachowemu gronu odbiorców, by stała się zachętą do dyskusji nad tłumaczeniem i zastosowanymi w nim rozwiązaniami.

\footnotetext{
${ }^{27}$ Stanisław BARAŃCZAK, Ocalone $w$ thumaczeniu: szkice o warsztacie tlumacza poezji z dodatkiem małej antologii przekładów-problemów (Kraków: Wydawnictwo a5, 2004), 15.

${ }^{28}$ Ibidem, 15.

${ }^{29}$ Ewa SKwARA, „Muza na nierównych kołach - czyli o przekładzie dystychu elegijnego w Ars amatoria Owidiusza”, Przekładaniec nr 1-2(2007): 55-70; Mieczysław BROŻEK, „O tłumaczu i tłumaczeniu myśli wybrane", Meander 51, nr 7-8(1996): 397-400.

${ }^{30}$ Bartłomiej Czarski omawiając cechy duetów stemmatycznych zamieszczanych na jednej karcie podaje przykład takiego układu w odniesieniu do dwóch herbów: Dąbrowa, którym pieczętował się św. Stanisław Kostka, oraz Jastrzębiec - herbu biskupa chełmskiego Krzysztofa Żegockiego. Epigram umieszczony pod nimi zawiera odniesienie do wspólnego motywu pojawiającego się w godłach herbów:
}

Utraque lux soleae meritorum splendet ab usu Et gentilitiae durat honore domus. Utraque signatur crucibus, non dispare quidni Stemmate vos similes et pietate pares?

Przekład autora opracowania podany w przypisie 397 brzmi następująco: „Blask obu podków lśni dzięki zasługom i umacnia rody w zaszczycie szlachectwa. Obie podkowy tak samo ozdobione są krzyżami. Czyż nie jesteście sobie równi i herbem i wiarą?”; CZARSKI, Stemmaty, 260-261.

${ }^{31}$ SKWARA, Muza, 60 . 


\section{Epigramaty $^{32}$}

1827:

Quem populi plausu, Procerum quem voce petebas, Aspice Pastorem, Plebs sitibunda Tuum -

En novus auspiciisque redit felicibus annus, Dum frueris Sponso, Praesule Sponsa Tuo.

In festos laeti applausus effundimur omnes, Praesul adest, et adest Pastor et omne decus. Ergo Pastori cum voto dicite cuncti, Ut vivat nobis saecula mille beans.

Ep. I

Spójrz, ludu spragniony, to Pasterz, którego Przyzywał lud wierny i możni -

Pod wróżbą szczęśliwą już nowy rok bieży, A ty swym biskupem się cieszysz.

Więc wszyscy radosne okrzyki wznosimy, Tu Pasterz, tu nasza ozdoba.

Składajcie więc wszyscy życzenia swe jemu

Niech długo, szczęśliwie nam żyje.

$1828^{33}$ :

Tales sunt in Te dotes dignissime Pastor,

Custos in populum, quem moderare vigil.

Amplis ut nequeant fastis calamisque notari.

Omnes vitae sunt integritate probae.

Ingemines splendore dies, ac sorte favente,

Exhilarando gregem, tristia fata doma.

Ep. II

Pasterzu czcigodny i w dary zasobny,

Jak stróż swym ludem kierujesz.

W kroniki największe Twe dary kto wpisze?

Twe życie to wzór nieskalany.

Ach, podwój dni sławne, a szczęście niech sprzyja.

Ciesz trzodę, złe losy pokonuj.

1829:

Pervigil in studio verae virtutis haberi,

Quisquis amat summo fulgeat honore.

Hoc agit clarus vitae probitate Iosephus,

${ }^{32}$ Zamieszczony w artykule łaciński tekst epigramatów stanowi ich edycję. Tłumaczenie epigramatów zostało dokonane przez Agnieszkę Strycharczuk, współautorkę artykułu.

${ }^{33}$ Epigramat ten jest powtórzeniem utworu znajdującego się w rubryceli na rok 1817, dedykowanego biskupowi lubelskiemu Wojciechowi Skarszewskiemu herbu Leszczyc. Pojawia się także jako utwór poświęcony biskupowi Dzięcielskiemu w rubryceli na rok 1835. 
In summo positus dum pietate micat.

Exemplo prodestque aliis et fortibus urget:

Pastoris, lux est optima, vita boni.

Ep. III

Kto cnoty prawdziwej chce czujnym być stróżem,

Niech błyszczy na wielkim urzędzie.

Tak czyni ów Józef, co w życiu swym prawym

Na szczycie lśni pobożnością.

Przykładem więc służy i innych przynagla,

Bo życie Pasterza jest światłem.

1830:

Principio rubri sacri stans cum levi Corvus

Mystis et populis utile monstrat iter:

Anni praesentis decurrant tempora fausta

Omnes et teneant pascua sancta sibi

Ergo Pastori cum voto dicite cuncti,

Ut vivat nobis saecula mille beans ${ }^{34}$.

Ep. IV

Na skromnym początku rubryceli ${ }^{35}$ stojąc,

Kruk-Kapłan drogę wskazuje.

Niech rok ten upływa szczęśliwie, a wszystkim

świętej niech strawy nie braknie.

Więc jemu składajcie życzenia swe wszyscy,

Długo, szczęśliwie niech żyje.

1831:

Josephum stellae segetes sol, luna colebant,

Hoc nomen primum Lublinum nostra colit.

Ille dedit pressis longa fame Corporis escas

Noster oves satiat sat meliore cibo.

Ep. V

Józefa uczciły gwiazdy, słońce, księżyc,

To Imię nasz Lublin czci najpierw.

Tamten w latach głodu dał pokarm cielesny,

Nasz owcom swym lepszą da strawę.

1832:

Ut sol in coelis, ut lux in sole videtur,

Virtus in vultu sic radiare Tuo;

Spectator quicunque venit, discedit amator,

Aut illum virtus aut Tua sanctitas capit.

\footnotetext{
${ }^{34}$ Ostatnie dwa wersy powtórzone za epigramatem z rubryceli na rok 1827.

${ }^{35}$ Wiersz powitania, 59: „O, jak dzielnie jest karta święta ozdobiona!”.
} 
Ep. VI

Jak słońce na niebie, a na nim blask widać,

Tak cnota na twarzy Twej świeci.

Kto przyszedł zobaczyć, odchodzi kochając,

Twą cnotą, świętością ujęty.

1833:

Exulat hinc error, clerus pietate coruscat,

Praesulem salvifica dum videt ire via.

Nec Tuus, o Praesul, clerus pietate tepescet,

Cui Tu exemplaris semitta, norma, manes.

Ergo praei, Pastor, clero, Te clerus in omni,

Re sequitur, donec caelica vita detur.

Ep. VII

Stąd grzech się oddala, świętością kler świeci, gdy Biskup na drodze zbawienia.

Niech kler twój, Pasterzu, w świętości nie słabnie,

Tyś dlań jest przykładem i wzorem.

Idź przeto, Pasterzu, przed klerem, by wiernie,

podążał, aż niebo osiągnie.

$1834^{36}$ :

Ut Tibi pro meritis tantis Amplissime Praesul

Cum bene non segni, sollicitudine obis.

Pastoris munus praegrande, et Christi in ovile

Impendis cura pervigili excubias:

Qui mentes hominum ex alto, cernitque probatque

Persolvat tanti muneris officium.

Ep. VIII

Dla wielkich Twych zasług, Prześwietny Biskupie,

Co brzemię trosk nosisz bez trudu.

Pasterski urząd sprawując i pieczę

Czujnego stróża w owczarni.

Niech Bóg, co człowieczą myśl z góry dostrzega,

Za wielką Twą służbę odpłaci.

$1835^{37}$ :

Tales sunt in Te dotes dignissime Pastor,

Custos in populum, quem moderare vigil.

Amplis ut nequeant fastis calamisque notari.

Omnes vitae sunt integritate probae.

\footnotetext{
${ }^{36}$ Epigramat ten jest powtórzeniem utworu znajdującego się w rubryceli na rok 1816, dedykowanego biskupowi lubelskiemu Wojciechowi Skarszewskiemu herbu Leszczyc.

${ }^{37}$ Epigramat ten jest powtórzeniem utworu znajdującego się w rubryceli na rok 1817, dedykowanego biskupowi lubelskiemu Wojciechowi Skarszewskiemu herbu Leszczyc. Pojawia się także jako utwór poświęcony biskupowi Dzięcielskiemu w rubryceli na rok 1828.
} 
Ingemines splendore dies, ac sorte favente, Exhilarando gregem, tristia fata doma.

\section{Ep. IX}

Pasterzu czcigodny i w dary zasobny,

Jak stróż swym ludem kierujesz.

W kroniki największe Twe dary kto wpisze?

Twe życie to wzór nieskalany.

Ach, podwój dni sławne, a szczęście niech sprzyja.

Ciesz trzodę, złe losy pokonuj.

$1836^{38}$ :

Vis animi generosa tui, de sanguine prisco

Corvitorum $^{39}$, Nobilitate nitet.

Sic clarere tamen, minus est Tibi, nisi Tua Virtus

Te clarum reddat; quod probitate facis

Nobilitas auro similis, quos ornat, in illis

Gemma velut, virtus et proba vita, micat.

Ep. X

Siła Twego ducha szlachectwem jaśnieje,

Z prastarej krwi Kruka potomków.

Jednak taka sława - mniej znaczy dla Ciebie,

Bo cnota sławnym Cię czyni.

Szlachectwo jak złoto jest w tych, których zdobi,

Klejnotem jest cnota i prawość.

1837:

Stirps generosa Tibi, sed nec minor adfuit ipsa,

Virtus, quae superat stemmata clara Patrum.

Dulcis in alloquio cunctis Tua pectora luce,

Et pura fuerunt candidiora nive.

Qua propter vivis fama celeberrimus ex Te,

Clerus virtutes, quas imitetur habet.

\section{Ep. XI}

Twój ród jest szlachetny, lecz cnota nie mniejsza,

Nad herby ojców jest wyższa.

Mową wszystkim miły, Twe myśli są światłem,

I czyste, jaśniejsze od śniegu.

Żyjesz przeto w sławie, a kler znakomity,

Iść może za cnót twych przykładem.

${ }^{38}$ Epigramat ten jest powtórzeniem utworu znajdującego się w rubryceli na rok 1819, dedykowanego biskupowi lubelskiemu Wojciechowi Skarszewskiemu herbu Leszczyc.

${ }^{39} \mathrm{~W}$ epigramacie z rubryceli na rok $1819 \mathrm{w}$ tym miejscu pojawia się forma Acervitatum odnosząca się do przedstawicieli herbu Leszczyc. 
1838:

Stemmate stirps nigrum defert Dzięcielsciana Corvum,

Corvinam unde domum fama vetusta canit.

Sed morem et vocem Corvus mutasse videtur,

Dulciter ut dulcis dum Philomela canit.

Quid canit? Auditur Dzięcielsciana musa per orbem,

Illius cantus audit et ipse Deus.

\section{Ep. XII}

Herb rodu Dzięcielskich czarnego ma Kruka,

Stąd $z$ dawna Korwinów dom sławny.

Jak widać Kruk zmienił i głos, i zwyczaje,

I słodko jak słowik on śpiewa.

Co śpiewa? Głos Muzy Dzięcielskiej w świat idzie,

I Bóg sam śpiewu jej słucha.

1839:

Quem virtus stimulat, cui verum corde resedit,

Cui pietas plaudet concomitata fide.

Ille mihi merito censendus magnus Antistes,

Atque illi soli praemia iure patent.

Ep. XIII

Kogo cnota wzywa, w czyim sercu prawda,

Pobożność w kim łączy się z wiarą,

Ten słusznie nazwany jest wielkim kapłanem,

Otwarta jest przed nim nagroda.

\section{BIBLIOGRAFIA}

\section{ŹRÓDŁA}

Boniecki, Adam. Herbarz polski. T. V. Warszawa: Gebethner i Wolff, 1902.

NieSIECKI, Kasper. Herbarz polski. Wydanie Jan Nepomucen Bobrowicz. T. V. Lipsk: Gebethner i Wolff, 1840.

Ordo Divini Officii ad usum Dioecesis Lublinensis pro Anno Domini 1825. Authoritate et mandato Illustrissimi Excellentissimi ac Reverendissimi Domini Josephi Marcellini Jastrzębiec Dzięcielski Dei et Apostolicae Sedis gratia Episcopi Aratensis, Suffraganei et Praepositi Cathedralis Calissensis, Sede vacante Administratoris Generalis Dioecesis Lublinensis etc. etc. propositus. Varsaviae: Ad Sanctam Crucem, [1824].

Ordo Officii Divini ad usum Dioecesis Lublinensis pro Anno Domini 1826. Authoritate et mandato Illustrissimi Excellentissimi ac Reverendissimi Domini, Domini Josephi Marcellini Jastrzebiec Dzięcielski Episcopi Lublinensis propositus. Varsaviae: Ad Sanctam Crucem, [1825].

Ordo Officii Divini ad usum Dioecesis Lublinensis pro Anno Domini 1827. Propositus authoritate et mandato Illustrissimi Excellentissimi ac Reverendissimi Domini, Domini Josephi Marcellini Jastrzębiec Dzięcielski Episcopi Lublinensis. Varsaviae: Ad Sanctam Crucem, [1826]. 
Ordo Officii Divini ad usum Dioecesis Lublinensis pro Anno Domini Bissextili MDCCCXXVIII propositus authoritate et mandato Illustrissimi Excellentissimi ac Reverendissimi Domini, Domini Josephi Marcellini Jastrzębiec Dzięcielski Episcopi Lublinensis. Varsaviae: Ad Sanctam Crucem, [1827].

Ordo Officii Divini ad usum Dioecesis Lublinensis pro Anno Domini MDCCCXXIX propositus authoritate et mandato Illustrissimi Excellentissimi ac Reverendissimi Domini, Domini Josephi Marcellini Jastrzębiec Dzięcielski Episcopi Lublinensis. Varsaviae: Ad Sanctam Crucem, [1828].

Ordo Officii Divini ad usum Dioecesis Lublinensis pro Anno Domini MDCCCXXX propositus authoritate et mandato Illustrissimi Excellentissimi ac Reverendissimi Domini, Domini Josephi Marcellini Korvin Dzięcielski Episcopi Lublinensis, Senatoris Regni Poloniae, Magnae Crucis S. Stanislai Equitis Commendatoris. Varsaviae: Ad Sanctam Crucem, [1829].

Ordo Officii Divini ad usum Dioecesis Lublinensis pro Anno Domini MDCCCXXXI propositus authoritate et mandato Illustrissimi Excellentissimi ac Reverendissimi Domini, Domini Josephi Marcellini Korvin Dzięcielski Episcopi Lublinensis, Senatoris Regni Poloniae, Magnae Crucis S. Stanislai Equitis Commendatoris. Varsaviae: Ad Sanctam Crucem, [1830].

Ordo Officii Divini ad usum Dioecesis Lublinensis pro Anno Domini MDCCCXXXII Bissextili propositus authoritate et mandato Illustrissimi Excellentissimi ac Reverendissimi Domini, Domini Josephi Marcellini Korwin Dzięcielski Episcopi Lublinensis, Senatoris Regni Poloniae, Magnae Crucis ac S. Stanislai Equitis Commendatoris. Varsaviae: Ad Sanctam Crucem, [1831].

Ordo Officii Divini ad usum Dioecesis Lublinensis pro Anno Domini MDCCCXXXIII post bissextilem embolismalem primo propositus authoritate et mandato Illustrissimi Excellentissimi ac Reverendissimi Domini, Domini Josephi Marcellini Korwin Dzięcielski Episcopi Lublinensis, Senatoris Regni Poloniae, ac Magnae Crucis S. Stanislai Equitis Commendatoris. Varsaviae: Ad Sanctam Crucem, [1832].

Ordo Officii Divini ad usum Dioecesis Lublinensis pro Anno Domini Embolismali MDCCCXXXIV post bissextilem secundo propositus authoritate et mandato Illustrissimi Excellentissimi ac Reverendissimi Domini, Domini Josephi Marcellini Korwin Dzięcielski Episcopi Lublinensis, Magnae Crucis ac S. Stanislai Equitis Commendatoris. Varsaviae: Ad Sanctam Crucem, [1833].

Ordo Officii Divini ad usum Dioecesis Lublinensis pro Anno Domini MDCCCXXXV post bissextilem tertio propositus authoritate et mandato Illustrissimi Excellentissimi ac Reverendissimi Domini, Domini Josephi Marcellini Korwin Dzięcielski Episcopi Lublinensis, Magnae Crucis ac S. Stanislai Equitis Commendatoris. Varsaviae: Ad Sanctam Crucem, [1834].

Ordo Officii Divini ad usum Dioecesis Lublinensis pro Anno Domini Bissextili MDCCCXXXVI propositus authoritate et mandato Illustrissimi Excellentissimi ac Reverendissimi Domini, Domini Josephi Marcellini Korwin Dzięcielski Episcopi Lublinensis, Magnae Crucis ac S. Stanislai Equitis Commendatoris. Varsaviae: Ad Sanctam Crucem, [1835].

Ordo Officii Divini ad usum Dioecesis Lublinensis pro Anno Domini MDCCCXXXVII propositus authoritate et mandato Illustrissimi Excellentissimi ac Reverendissimi Domini, Domini Josephi Marcellini Korwin Dzięcielski Episcopi Lublinensis, Magnae Crucis ac S. Stanislai Equitis Commendatoris. Varsaviae: Ad Sanctam Crucem, [1836].

Ordo Officii Divini ad usum Dioecesis Lublinensis pro Anno Domini MDCCCXXXVIII propositus authoritate et mandato Illustrissimi Excellentissimi ac Reverendissimi Domini, Domini Josephi Marcellini Korwin Dzięcielski Episcopi Lublinensis, Magnae Crucis ac S. Stanislai Equitis Commendatoris. Varsaviae: Ad Sanctam Crucem, [1837]. 
Ordo Officii Divini ad usum Dioecesis Lublinensis pro Anno Domini MDCCCXXXIX propositus authoritate et mandato Illustrissimi Excellentissimi ac Reverendissimi Domini, Domini Josephi Marcellini Korwin Dzięcielski Episcopi Lublinensis, Magnae Crucis ac S. Stanislai Equitis Commendatoris. Varsaviae: Ad Sanctam Crucem, [1838].

Owidiusz. Przemiany. Tłumaczenie Bruno Kiciński, opracowanie Aleksander Krawczuk. Warszawa: Unia Wydawnicza „Verum”, 1995.

PAPROCKI, Bartosz. Gniazdo cnoty. Kraków: Drukarnia Andrzeja Piotrowczyka, 1578.

PAPROCKI, Bartosz. Herby rycerstwa polskiego, wydanie Kazimierz Józef Turowski. Kraków: Wydawnictwo Biblioteki Polskiej, 1858.

PотоскI, Wacław. Poczet herbów szlachty Korony Polskiej i Wielkiego Księstwa Litewskiego. Wstęp i opracowanie Dariusz Dybek. Warszawa: Raphael, 2008.

Szlachta wylegitymowana w Królestwie Polskim w latach 1836-1861. Opracowanie Elżbieta Sęczys. Warszawa: Wydawnictwo DiG, 2000.

URUSKI, Seweryn. Rodzina. Herbarz szlachty polskiej. T. III. Warszawa: Gebethner i Wolff, 1906.

Wiersz powitania Jaśnie Wielmożnego Józefa Marcellina Dzięcielskiego, Biskupa Lubelskiego, Senatora Królestwa Polskiego, roku 1826 w dniu 26 kwietnia jako w dzień imienin przez Właściwego Dyecezanina z Dekanatu Chodelskiego z przynależna skromnościa ofiarowany. Bmw, [1826].

\section{OPRACOWANIA}

BARAŃCZAK, Stanisław. Ocalone w tlumaczeniu: szkice o warsztacie tlumacza poezji z dodatkiem matej antologii przekładów-problemów. Kraków: Wydawnictwo a5, 2004.

BIEŃKOwski, Tadeusz. Antyk w literaturze i kulturze staropolskiej (1450-1750). Główne problemy i kierunki recepcji. Wrocław: Zakład Narodowy im. Ossolińskich, 1976.

BrożeK, Mieczysław. „O thumaczu i thumaczeniu myśli wybrane”. Meander 51, nr 7-8(1996): 397-400.

Buchwald-Pelcowa, Paulina. Emblematy w drukach polskich i Polski dotyczacych XVI-XVIII w. Wrocław: Zakład Narodowy im. Ossolińskich, 1981.

Buchwald-Pelcowa, Paulina. „Na pograniczu emblematów i stemmatów”. W Stowo i obraz. Materiały sympozjum Komitetu Nauk o Sztuce Polskiej Akademii Nauk, Nieborów, 29 września - 1 października 1977, red. Agnieszka Morawińska, 73-95. Warszawa: Państwowe Wydawnictwo Naukowe, 1982.

CzArski, Bartłomiej. Stemmaty w staropolskich ksiażkach, czyli rzecz o poezji heraldycznej. Warszawa: Muzeum Pałac w Wilanowie, 2012.

DZIĘCIELSKI, Marek. „Józef Marcellin Dzięcielski (1768-1839), biskup lubelski (1825-1839)”. Studia Pelplińskie 42(2010): 75-101.

Estreicher, Karol. Bibliografia polska. Cz. 3, t. XV. Kraków: Akademia Umiejętności, 1897.

Forstner, Dorothea. Świat symboliki chrześcijańskiej. Thumaczenie i opracowanie Wanda Zakrzewska, Paweł Pachciarek i Ryszard Turzyński. Warszawa: Instytut Wydawniczy PAX, 1990.

Godlewski, Michał. „Dzięcielski Józef Marcelin”. W Polski stownik biograficzny, t. VI, 179. Kraków: Polska Akademia Umiejętności, 1948.

GrotnIK, Kazimierz. Józef Marcellin Dzięcielski (biskup lubelski) 1825-1839. Hazleton: K. Grotnik, 1988. 
MACIEJOwSKI, Wacław Aleksander. Piśmiennictwo polskie od czasów najdawniejszych aż do roku 1830. T. I-IV. Warszawa: Nakładem S. Orgelbranda, 1851-1852.

MARCZEwski, Jarosław R. „Czas i miejsce urodzenia dwóch biskupów lubelskich: Józefa Marcelego Dzięcielskiego i Wincentego a Paulo Pieńkowskiego”. Archiwa Biblioteki i Muzea Kościelne 88(2007): 65-75.

Marczewski, Jarosław R. „Programowy list pasterski biskupa Józefa Marcelego Dzięcielskiego z 1827 roku". Wiadomości Archidiecezji Lubelskiej 80, nr 2(2006): 499-521.

Pelc, Janusz. Obraz - stowo - znak. Studium o emblematach w literaturze staropolskiej. Wrocław: Zakład Narodowy im. Ossolińskich, 1973.

PILARCZYK, Franciszek. Stemmata $w$ drukach polskich XVI wieku. Zielona Góra: Wydawnictwo Wyższej Szkoły Pedagogicznej, 1982.

Pszczołowska, Lucylla. „Potęga metrum: o Puszkinowskim przekładzie Czat”. Pamiętnik Literacki 92, z. 3(2001): 171-177.

SKARBEK, Jan. „Dzięcielski Józef Marceli”. W Encyklopedia katolicka, t. IV, 614. Lublin: Towarzystwo Naukowe KUL, 1983.

Skwara, Ewa. „Muza na nierównych kołach - czyli o przekładzie dystychu elegijnego w Ars amatoria Owidiusza". Przekładaniec nr 1-2(2007): 55-70.

STARNAwSKI, Zygmunt. „Józef Marcelin Dzięcielski 1768-1839, biskup lubelski 1826-1839”. Wiadomości Diecezjalne Lubelskie 59, nr 5-7(1985): 117-119.

STRYCHARCZUK, Agnieszka i Jarosław R. MARCZEWSKI. „Apoteoza godła heraldycznego biskupa Wojciecha Skarszewskiego w łacińskich wierszach herbowych w rubrycelach chełmsko-lubelskich i lubelskich". Roczniki Humanistyczne 63, z. 3(2015): 149-176.

\author{
APOTEOZA GOD $\angle A$ HERALDYCZNEGO \\ BISKUPA JÓZEFA MARCELEGO DZIĘCIELSKIEGO (1768-1839) \\ W ŁACIŃSKICH WIERSZACH HERBOWYCH W RUBRYCELACH LUBELSKICH
}

Streszczenie

Przedstawiony w niniejszym artykule zbiór trzynastu łacińskich wierszy herbowych poświęcony jest biskupowi Józefowi Marcelemu Dzięcielskiemu. Był on pasterzem diecezji lubelskiej w latach 1825-1839. Wiersze na herby znane są w obiegu literackim od XV wieku. Te, które pojawiają się w rubrycelach, są rzadko analizowane i tłumaczone. Dzieje się tak ze względu na elitarny charakter tych druków użytkowych, docelowo kierowanych do duchowieństwa danej diecezji. Warto przedstawić je szerszemu gronu odbiorców, ponieważ stanowią one także element dorobku literackiego epoki. Artykuł i analizowane w nim utwory przybliżają postać biskupa Józefa Marcelego Dzięcielskiego, jego herb i posługę.

Słowa kluczowe: herb Korwin; poezja herbowa; biskup Józef Marceli Dzięcielski; diecezja lubelska; rubrycele. 


\title{
APOTHEOSIS OF THE COAT OF ARMS \\ OF BISHOP JÓZEF MARCELI DZIĘCIELSKI (1768-1839) IN THE LATIN HERALDIC POEMS IN THE ORDOS OF THE DIOCESE OF LUBLIN
}

\begin{abstract}
Summary
The collection of thirteen Latin heraldic poems presented in this article was dedicated to Bishop Józef Marceli Dzięcielski. He was a shepherd of the Diocese of Lublin in the years 18251839. The heraldic poems have been known in literary circuit since the 15 th century. Those that appeared in dioecesan ordos have been rarely analyzed and translated. This is due to the elitist nature of these usable prints, ultimately directed to dioecesan clergy. It is all the more worth presenting them to a broader audience, as they are also an element of the literary output of the era. The article and the poems analyzed in it bring some more knowledge of Bishop Józef Marceli Dzięcielski, of his coat of arms, and of his ministry. They can also provoke a discussion on the completed translation and the solutions applied in it.
\end{abstract}

Key words: Korwin coat of arms; heraldic poetry; Bishop Józef Marceli Dzięcielski; the Diocese of Lublin; ordo. 